\title{
Application of Android-Based Blood Donors in Palang Merah Indonesia in Sumbawa District as A Report of Support to Sumbawa Smart City Movement
}

\author{
Muhammad Hidayatullah ${ }^{1}$, Satria Junanda ${ }^{2}$ \\ ${ }^{1}$ Department of Electrical Engineering, Faculty of Engineering, Universitas Teknologi \\ Sumbawa, Indonesia. 84317 \\ ${ }^{2}$ Department of Informatics, Faculty of Engineering, Universitas Teknologi Sumbawa, \\ Indonesia. 84317 \\ \{mhhidayat07@gmail.com¹, satrialin34@gmail.com²
}

\begin{abstract}
This study aims to build an android-based blood donor application, an android-based blood donor application at PMI Sumbawa Regency. This application was developed with the Java programming language using Android Studio, MySql and Firebase as a database. Software development method using Prototype Model. Software testing is done through Beta Testing. Data collection techniques in research using observation, documentation and interviews. The result of this study is an android-based blood donor application that is useful to help the community to get information regarding blood donors at PMI Sumbawa Regency and become one of the forms to support the Sumbawa Smart City Movement.
\end{abstract}

Keywords: Application, Donor, Android, Prototype, Sumbawa.

\section{Introduction}

Blood donation is a voluntary process of giving blood for the purpose and purpose of blood transfusion for other people in need. One in four people in the world may need blood transfusions during their lifetime, but only $37 \%$ of the population is eligible to donate blood and only under $10 \%$ want to donate their blood regularly. Blood needs per year for an area is $2 \%$ of the population of the area. Blood donors are very important but often forgotten. Blood donors are useful for palliative care that focuses on patients with serious or life-threatening diseases [1].

One of the organizations engaged in blood donation in Sumbawa Regency, namely the Indonesian Red Cross (PMI). The process of delivering information related to blood donors, the community must always come to PMI, so that it is inefficient and ineffective. Many want to donate blood to help others, but because the information is still lacking, people do not know how to get information, schedules and blood donor activities that exist. Information about blood donor activities needs to be known by the general public, especially for the Sumbawa Regency area.

Based on data obtained from the Sumbi Regency PMI IT team namely Mr. Yunan Saptawansyah, that there are several obstacles, namely, information on blood supply, blood donor events and blood donor locations are still manual so that people have difficulty in 
getting information regarding blood donors [2]. Therefore, it is necessary to develop an information system in the form of "Android-based Blood Donation Application in Sumbawa Regency", so that it can help disseminate information regarding effective blood donors to support the information needs of the community regarding the Sumbawa PMI.

With the existence of an Android-based Blood Donation Application in Sumbawa Regency, it is expected to provide solutions and help agencies to support the Sumbawa Smart City Movement in providing information on blood stocks, blood donor events and blood donor locations. So that the community gets the latest information (up to date) regarding blood donations efficiently through their android smartphone.

\section{Material and Method}

The system development method that I use in this study is the prototyping method [3], which is a process used to create a model of Android-based Blood Donor Application in PMI Sumbawa Regency in stages The following stages in software development use the prototype model:
a. Early Data Communication and Collection
At this stage the communication process is carried out with the Sumbawa PMI IT team, to get an initial picture of the applications to be built.
b. Quick Design
At this stage, a rapid design and modeling process is carried out for Android-based Blood Donor Applications in PMI, Sumbawa Regency in general, to be further developed.
c. Formation of Prototype
In this modeling stage, the process of making an Android-based Blood Donor Application in the PMI Regency of Sumbawa includes the testing and refinement.

\section{Results and Discussion}

The following is a proposed system design using object-oriented design [4][5] carried out in the manufacture of Android-based Blood Donor Applications in PMI Sumbawa Regency:

\section{Application Overview}

In general description this application explains the application flow contained in AndroidBased Blood Donor Application in PMI Sumbawa Regency. First the user must log in then after the data is verified it will be directed to the main menu where there are 8 menus in the Android-based Blood Donor Application in the PMI Regency of Sumbawa, namely: profile menu, blood statistics menu, news and event menu, admin contact menu, requirement menu blood donor, location menu, menu about us and the app share menu. The general description of the Android-based Blood Donor Application in Sumbawa Regency is as follows

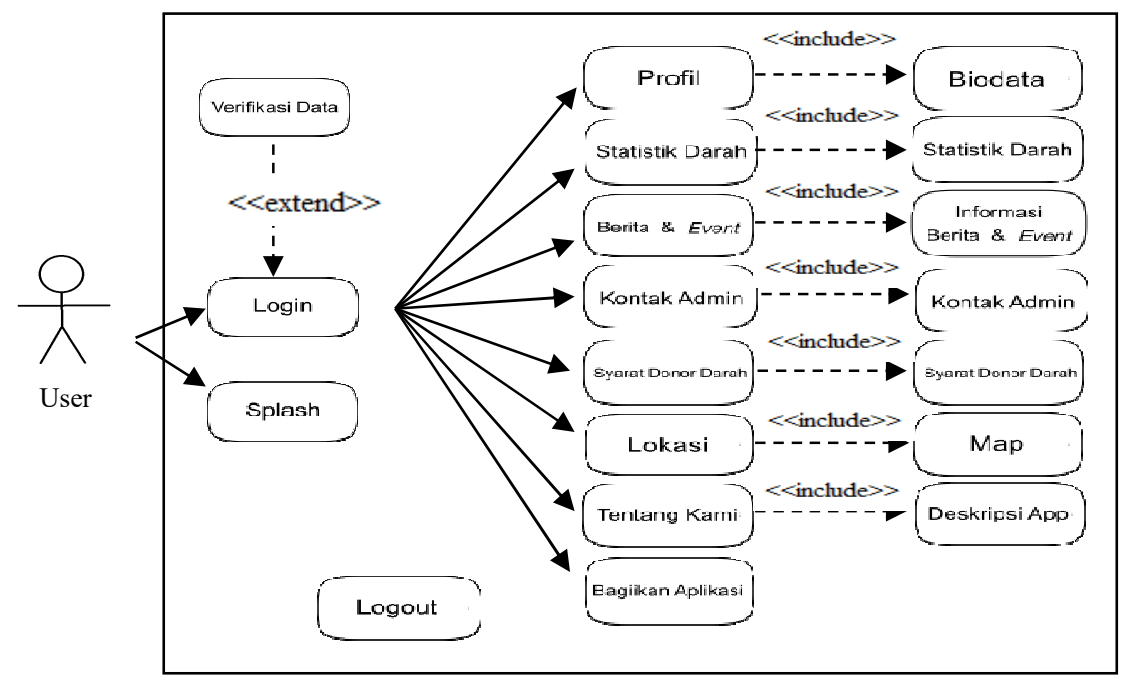


Fig. 1. Application Overview

\section{Use Case Diagram}

Use Case Diagram describe the relationship between system users (actors) with activities or processes in an android-based blood supply application. In this application there are 2 actors, namely Admin and User. To explain the Use Case diagram of the application that will be built, it is explained in the Use Case specifications of each actor.

a. Admin Section Use Case Diagram

Admin section use case diagram on the Android-based Blood Donor Application can be seen in Figure 2 below:

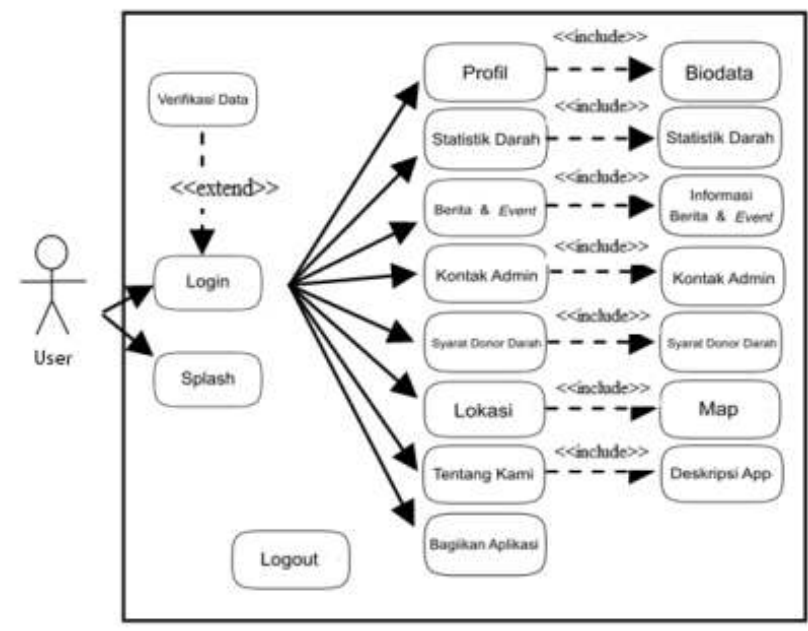

Fig. 2. Admin Section Use Case Diagram

In the Fig. 1, the admin actor can access the home, manage donor data, and manage blood supply, and also manage news on the server.

b. User Section Use Case Diagram

User section use case diagram on the Android-based Blood Donor Application can be seen in Figure 3 below: 


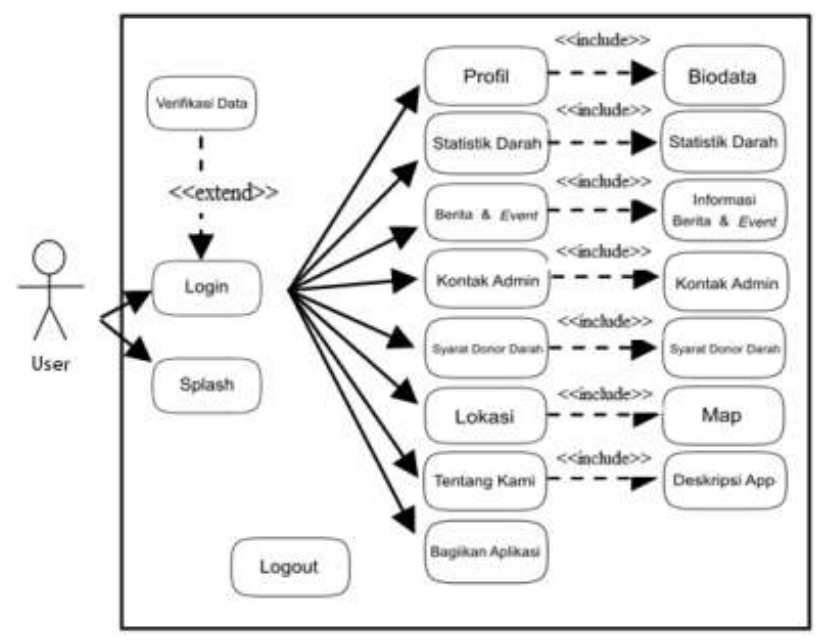

Fig. 3. User Section Use Case Diagram

In the picture above the user can access profiles, blood statistics, news and events, admin contacts, blood donor requirements, location, about us, share the application, and logout after logging in to the application.

\section{User Interface Design at Admin}

Following is the design of the admin interface on the Android-based Blood Donor Application:

\section{a. Design of Admin Main Page}

Initial display when the admin runs the dashboard of Android-Based Blood Donor Application at PMI in Sumbawa Regency showed in Fig. 4:

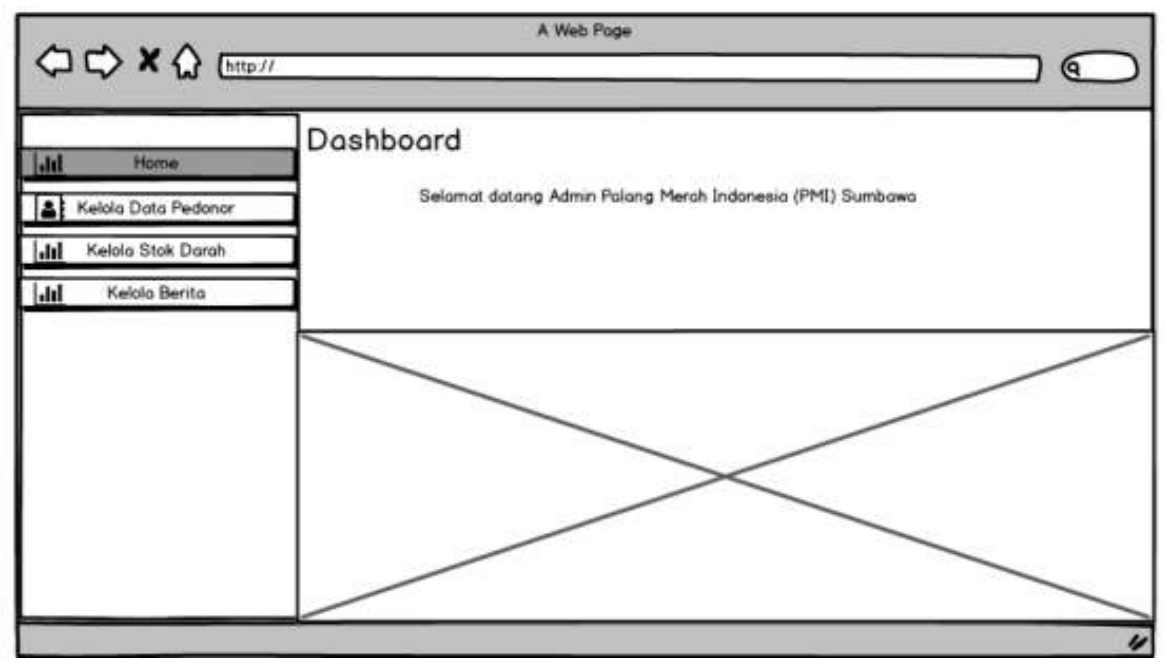


Fig. 4. Design of Admin Main Page

The picture above is the initial display when the admin first opens the dashboard application with a four button menu, namely the home button, the managing button for donor data, the managing button for blood supply and the news management button.

b. Manage Admin Side Donor Data Design

The following is a draft menu for managing donor data on the dashboard of AndroidBased Blood Donor Applications at PMI in Sumbawa Regency:

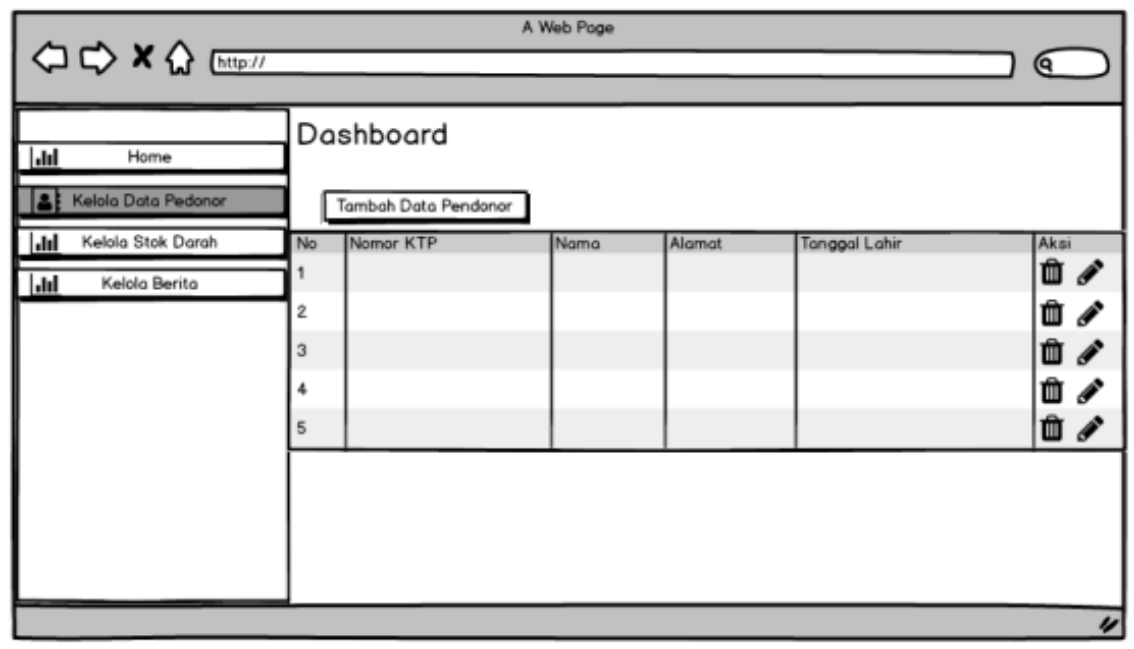

Fig. 5. Manage Admin Side Donor Data Design

In the design picture of the donor data management menu above the author designed the display menu of the donor data management from the Android-based Blood Donation Application Dashboard in PMI Sumbawa Regency with a menu editor to change data. Design of User Interface on Users

The following is the design of the user interface on the Android-based Blood Donation Application:

a. Login Design

The following is a draft login for the Android-based Blood Donor Application at PMI in Sumbawa Regency: 


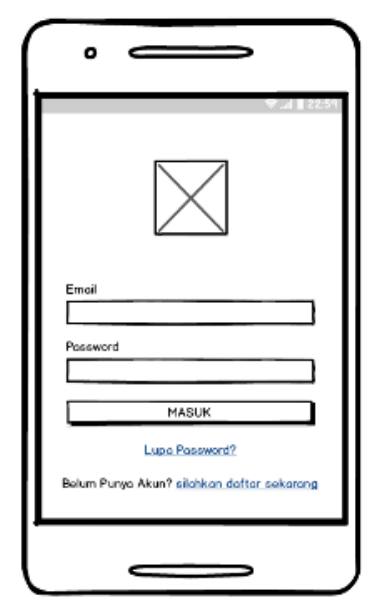

Fig. 6. User Login Design

In the login design image there are two edit texts for inputting e-mails and passwords and a button for logging into the application.

b. Main Menu Design

The following is the main menu design for Android-based Blood Donor Applications at PMI Sumbawa Regency:

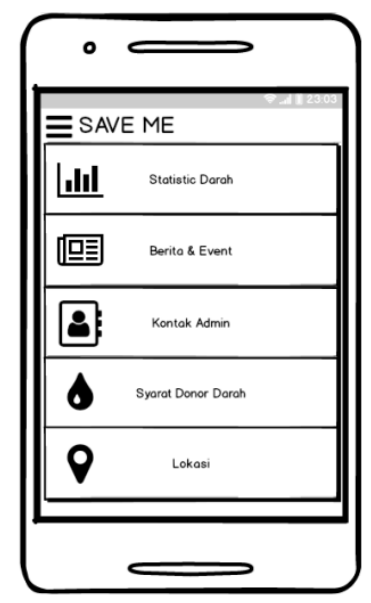

Fig. 7. Main Menu Design

In the main menu design drawings, there are five menus, namely the blood statistics menu, news and event menu, admin contact menu, blood donor requirements and location menu.

Program Implementation 
The following is the implementation of the program from the Android-based Blood Donor Application in PMI Sumbawa Regency:

1) Admin Interface Implementation

Implementation of Admin Panel Start Display

The following image is the admin's initial appearance when the admin enters the admin panel:

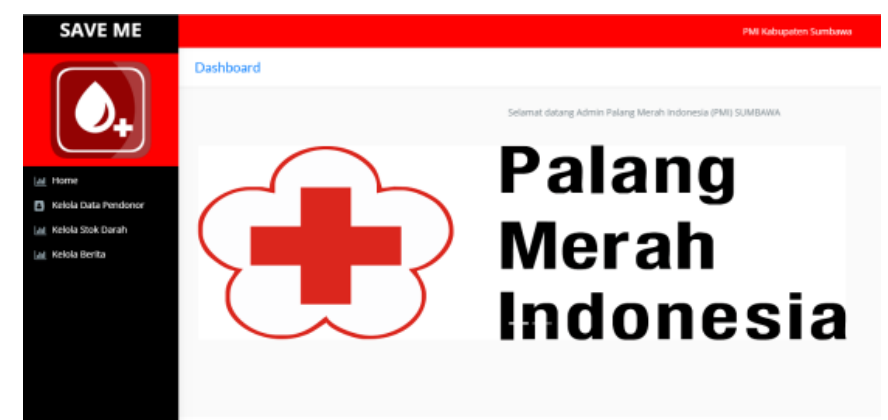

Fig. 8. Implementation of Admin Panel Start Display

Implementation of the admin panel's initial display, where there are buttons as menus that must be managed by data, namely managing donor data, managing blood supply and managing news.

\section{Implementation of the Donor Data Manage Display}

The following image is managing donor data when the admin enters the admin panel:

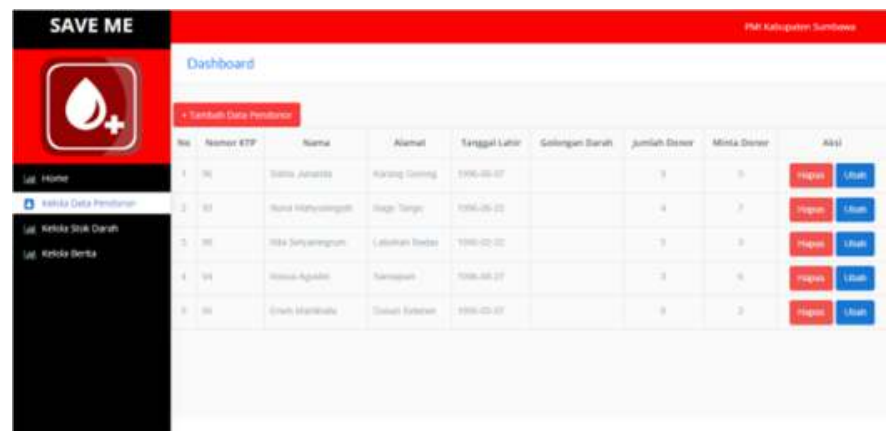

Fig. 9. Implementation of Display Data Manage 
Implementation of admin view managing donor data, where there is data on ID card number, name, address, and date of birth of each blood donor. Admin can edit the data with the editor menu.

2) Implementation of User Interface

Implementation of User Login Display

The following picture is the appearance of the user when the user will access the application:

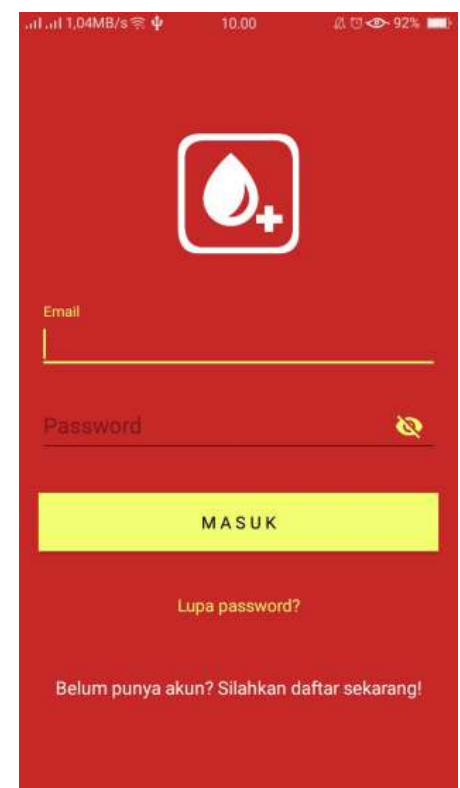

Fig. 10. Implementation of Login Display

In the picture above there is an imageview for the logo, edittext to enter the email and password and button to $\log$ in.

\section{Implementation of Menu / Home Views}

The following picture is the initial appearance of the user when opening the application: 


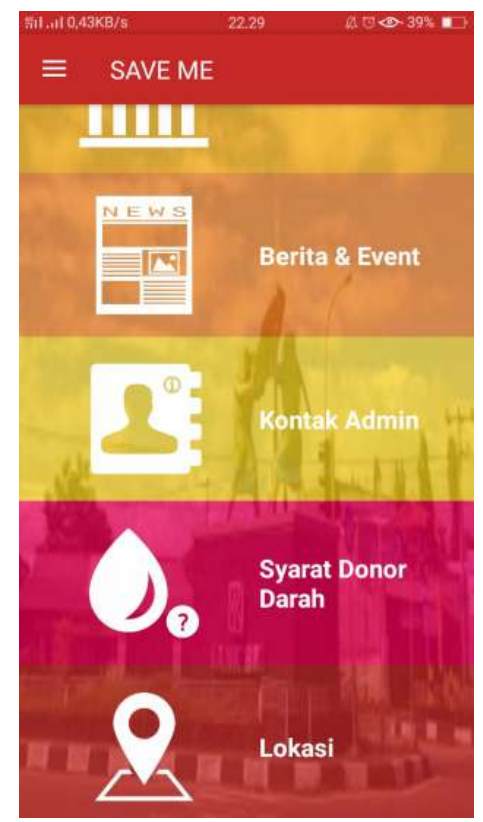

Fig. 11. Implementation of Menu / Home Views

In the initial display there is an action bar for the drawer and title and button as a menu of blood statistics, news and events, admin contacts, blood donor requirements, and location.

\section{Display Implementation}

See Menu Statistics The following picture is a view to see the menu of blood statistics in the application:

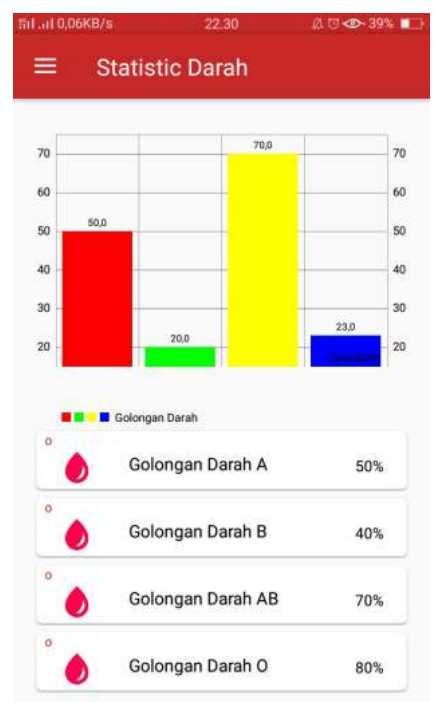


Fig. 12. Display Implementation for See the Blood Statistics Menu

In the blood menu display, there is an action bar for the drawer and title, the imageview for the blood static diagram and button for detailed blood supply.

\section{Display Implementation}

See News and Event Menu The following picture is a view to see the news menu and events in the application:

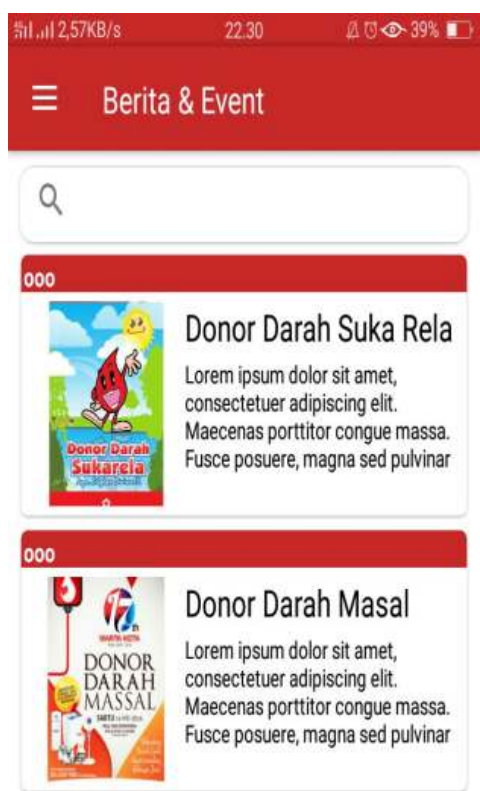

Fig. 13. Display Implementation for See News and Event Menu

\section{Software Testing}

The testing process is carried out to 10 respondents who are directly related to the application that has been built. Based on the results of the questionnaire after calculation, conclusions can be drawn on the assessment of the application that has been built.

Calculation of questions and answers from the results of questionnaires that have been shared with examiners using the formula [6]:

$$
\mathrm{Y}=\mathrm{P} / \mathrm{Q} * 100 \%
$$

Where,

$$
\begin{aligned}
& \mathrm{Y}=\text { Percentage Value } \\
& \mathrm{P}=\text { Many respondents answer each question } \\
& \mathrm{Q}=\text { Number of respondents }
\end{aligned}
$$

The following are the results table of testing with beta test testing: 
Table 1. Table of testing with beta test testing

\begin{tabular}{llccc}
\hline No & \multicolumn{1}{c}{ Questions } & \multicolumn{2}{c}{ Frequency of Answers } \\
\cline { 2 - 5 } & \multicolumn{1}{c}{ Yes } & Enough & No \\
\hline 1. & $\begin{array}{l}\text { Is the information presented in the Android-based Blood } \\
\text { Donation application at the Sumbawa Regency PMI easy to } \\
\text { understand? }\end{array}$ & $70 \%$ & $30 \%$ & - \\
& & & \\
\hline 2. & $\begin{array}{l}\text { Is the Android-based Blood Donation application at PMI } \\
\text { Sumbawa Regency easy to use? }\end{array}$ & $70 \%$ & $20 \%$ & $10 \%$ \\
\hline 3. & $\begin{array}{l}\text { Does the Android-based Blood Donation application at PMI } \\
\text { Sumbawa Regency appeal to you? }\end{array}$ & $50 \%$ & $40 \%$ & $10 \%$ \\
\hline 4. & Are you interested in using this application again? & $80 \%$ & $10 \%$ & $10 \%$ \\
\hline 5. $\quad \begin{array}{l}\text { Can the Android-based Blood Donation application at PMI } \\
\text { Sumbawa Regency help agencies and the community? }\end{array}$ & $90 \%$ & $10 \%$ & - \\
\hline 6. & Is this application worthy of dissemination? & $100 \%$ & - & - \\
\hline
\end{tabular}

Based on the answers given by the respondents it can be concluded that the Androidbased Blood Donor Application in PMI Sumbawa Regency is 70\% easy to understand and use, $90 \%$ can help agencies and the community, and $100 \%$ of respondent state that the application deserves to be disseminated.

\section{Conclusions}

Android-based Blood Donation Application in Sumbawa Regency has been successfully designed using android studio 2.2.3., where applications with facilities are equipped to view information about blood supplies and provide map direction services that make it easy to find locations related to news and blood donor events. that is in PMI Sumbawa Regency automatically through the Gadget. With testing that concludes that $70 \%$ are easy to understand and use, $90 \%$ can help agencies and communities, and $100 \%$ of respondense state that the application is worth dissemination, the results of this study can be input for the Sumbawa regional government to implement it as a form of movement support Sumbawa Smart City in Sumbawa Regency.

\section{Acknowledgements}

The author would like to thank United States Agency for International Development (USAID) for the training and mentoring support in writing this article, through the Sustainable Higher Education Research Alliance (SHERA) Program for Universitas Indonesia's Scientific Modeling, Application, Research and Training for City-centered Innovation and Technology (SMART CITY) Project.

\section{References}

[1] Castaka Agus Sugiatno, Teguh Muhammad Zundi: Rancang Bangun Aplikasi Donor Darah Berbasis Mobile di PMI Kabupaten Bandung. Jurnal Ilmiah Manajemen Informatika dan Komputer, Vol. 01, No. 01, pp. 11-18, 2017. ISSN: 2549-211X (2017) 
[2] Yunan Saptawansyah: Wawancara Kondisi Tata Kelola Donor Darah Palang Merah Indonesia (PMI) Kabupaten Sumbawa (2018)

[3] Purnomo, Dwi.: Model Prototype pada Pengembangan Sistem Informasi. Jurnal Informatika Merdeka Pasuruan, Vol. 02, No. 02, pp. 54-61. ISSN : 2503-1945 (2017)

[4] Gusriva, Revi.: Analisa dan Perancangan Berorientasi Objek pada Website Rencana Pengembangan Pendidikan Dasar Kota. UPI YPTK Jurnal KomTekInfo Vol. 4, No. 2, pp. 204-213. ISSN:2356-0010 (2017)

[5] Sofya N. D.: Rancang Bangun Aplikasi Kamus Bahasa Sumbawa Berbasis Android. Jurnal Matrik, Vol 17 No1 , pp. 36-45. ISSN : 1858-4144 (2017)

[6] Gunawan, H dan Shinta E.: Rancang Bangun Pengenalan Alat Musik Tradisional Sumbawa Berbasis Android. Jurnal Matrik, Vol. 18, No.1, pp. 73-85 (2018)

[7] Fowler, Martin.: UML Distilled 3th E, Panduan Singkat Bahasa Pemodelan Objek Standar. Andi. Yogyakarta (2005)

[8] Hidayatullah, Muhammad.: Pengukuran Konsentrasi Larutan Sodium Hidroksida $(\mathrm{NaOH})$ Dengan Transduser Kapasitif, Jurnal Ilmu Fisika (JIF) Vol. 10 (1), Hal. 1727 (2018)

[9] Hariyanto, Bambang.: Esensi-esensi Bahasa Pemrograman JAVA (Revisi), Informatika, Bandung (2015)

[10] Hidayatullah, M.: Sistem kendali keran otomatis menggunakan sensor Passive InfraRed (PIR) berbasis mikrokontroler ATMega8535L untuk menghemat penggunaan air, Jurnal Tambora Universitas Teknologi Sumbawa, Vol. 1(3), pp 34$35(2016)$

[11] Kurniawan, A.: Rekayasa Perangkat Lunak Aplikasi Penjualan Pada Toko Story Time Factory Outlet Menggunakan Pemrogram Java. Jurnal Universitas Andalas, hlm. 3 (2013)

[12] Darytamo, B. dkk.: Pemrograman Berorientasi Obyek dengan Java 2 Platform Micro Edition (J2ME). Bandung (2007)

[13] Hidayatullah, Muhammad.: Pengukuran Konsentrasi Larutan Gula Menggunakan Transduser Kapasitif, Jurnal Ilmu Fisika (JIF) Vol. 9, Hal. 43-56 (2017)

[14] Agus Ristono.: Manajemen Persediaan Edisi 1. Yogyakarta: Graha Ilmu (2009)

[15] Hidayatullah, M.: Prototype Sistem Telemetri Pemantauan Kualitas Air Pada Kolam Ikan Air Tawar Berbasis Mikrokontroler, Jurnal Positron Universitas Tanjung Pura, Vol. 8 (2), DOI: 10.26418/positron.v8i2.27367 (2018) 